reader in dynamical astronomy and then, in 1928, professor of mathematics, which post he held until his retirement in 1948. He became head of the Department when Prof. T. H. Havelock (now Sir Thomas Havelock) retired, and as Sub-Rector of King's College during 1942-47, he played a most valuable part in seeing the College through difficult war-time years and those of the post-war expansion which was taking place. He was awarded the C.B.E. in 1948 for his work as chairman of the Durham University Joint Recruiting Board.

Although the dynamical theory of tides was his first and continuing interest in mathematical research and his papers on this subject appeared until 1954, mostly in the Proceedings of the Royal Society, the work that created most interest at the time was his theory of Saturn's rings. A theory of this unique ring system had been given by J. Clerk Maxwell in 1856, who concluded that it was composed of meteorites moving in circular orbits round the planet. The divisions in the ring system had to be accounted for, and the suggestion had been made that they were due to zones of instability around the planet set up by the satellites. In a fundamental paper in the Philosophical Transactions of the Royal Society (1922), which was followed by two papers in the Proceedings, Prof. Goldsbrough examined the influence of the satellites of Saturn on its ring system, on the basis of Maxwell's theory, and he was able to account for divisions in certain zones which were in good agreement with the salient observed features. For this work he was elected Fellow of the Royal Society in 1929. He returned to the subject again in 1941, when by a different method of solving the intricate perturbation problem, he clarified some points of criticism of his earlier work, and in 1951 he showed that, under conditions satisfied by the Saturnian rings, a pair of rings forms a stable system.

Prof. Goldsbrough had a clear, straightforward approach to any problem in hand, which, combined with his absolute integrity, led to his being much sought after as a counsellor in University affairs. He had an interest in all aspects of astronomy, and on many occasions gave lectures at meetings of the Neweastle upon Tyne Astronomical Society of which he was president during 1944-61. His wife died a few years ago, and he is survived by three danghter's.

$$
\text { C. Grlbert }
$$

\section{Prof. W. H. Lewis}

William Henry Lewis, who died on May 25 at the age of ninety-four, was educated at University College, Aberystwyth, and Jesus College, Oxford. After seven years (1894-1901) as science master at Exeter School, he joined the staff of the embryonic University College, Exeter, where he held the chair of ehomistry from 1901 until 1935; he was vice-principal of the Collego from 1925 until 1935.

In the first few years of his tenure of the chair at Exeter, Lewis carried out research in organic chemistry and published a number of papers in collaboration with the late Dr. F. D. Chattaway, then at St. Bartholomew's Hospital Medical School. However, he soon found himself fully occupied with the affairs of the struggling young college and during the last thirty years of his occupancy of the chair devoted himself entirely to promoting the interests of the College and of his Department. During the First World War, Lewis, together with his colleagues, the late Prof. W. J. Harte and Prof. A. F. Morgan, was instrumental in the setting up of a Committee for the Furtherance of University Education in the South-west; there is no doubt that it was Lewis's devoted work as a secretary of this Committee which sowed the first seeds of growth which led, in due course, to the foundation, by Royal Charter in 1955, of the University of Exeter. Between the two World. Wars much hard work was needed to get the University College fully accepted and once again Lewis was a leading member of a small group of devoted men, without whose efforts nothing lasting could have been achieved. The University College signalized its appreciation of his services by making Lewis professor emeritus on his retirement and the University by conferring on him, in 1957, the honorary degree of LL.D., a distinction which he greatly prized.

With all this, Lewis in no way neglected his Department. Starting from almost nothing, he built up a strong and active department of chemistry, with a striking record of academic successes in the external degree examination of the University of London and a sound reputation for research, which Lewis fostered by attracting good men to his staff and seeing to it that they had the facilities they needed for their work. He was responsible for the planning of new chemical laboratories, in the Washington Singer Building, opened in 1931; it would surcly have pleased him to know that his old Department has now outgrown accommodation which must have seemed to many to be over-generous at the time.

Although so much involved in College affairs, Lewis found time to serve on the Council of the Royal Institute of Chemistry (1924-27) and on the External Council of the University of London (1930-35).

Lewis has rightly been called one of the founding fathers of the University of Exeter; as such he has an assured and honoured place in the history of English universities.

$$
\text { H. N. RYDON }
$$

\section{Dr. G. Arnold, O.B.E.}

Wrth the death on August 9, 1962, of George Arnold, not only has the scientific world lost a great scientist but also we, in Africa, are deprived of a figuro of outstanding morit, a redoubtable character.

Born in Hong Kong eighty-one years ago, his early education was undertaken, consecutively, in Devon, at Waldkirch in the Black Forest and at a senior school at Compiégne in France. He made full use of this early, varied education and, with his remarkably retentive memory, retained his knowledge of these languages throughout his days. After a spell of clerical work in London he com. menced his scientific career at the Royal College of Science, and followed this with an appointment in the Department of Cytology and Cancer Research at the University of Liverpool.

In 1911, at the age of thirty, he was appointed to the curatorship of the ten-year-old Rhodesian Museum in Bulawayo, which eventually expanded, through his leadership, to become the National Museum of Southern Rhodesia and, largely through his investigations, an institute of international repute. Director of the Museum until 1947, he was for many years the only zoologist (in the wide sense) on the staff. Always outstandingly neat, a rare gift for a museum specialist, he was adept at casting reptiles and fish, adding all the intricate finishing touches himself.

Apart from building up vertebrate and insect collections his primary scientific interest was in the Aculeate Hymenoptera. Probably his carliest publication was a joint paper with J. E. S. Moore, director of eancer research. This was "On the Existence of Permanent Forms among the Chromosomes of the First Maiotic Division in Certain Animals", published in the Proceedings of the Royal Society (1905). This was followed by papers on chromosomes in Hydrophilus, on ovigenesis and on digestion in Planaria, on blood, epithelia and chondriosomes, the last of these cytological articles in 1912. Then, in 1912, Arnold read. a paper to the Rhodesia Scientific Association on the "Foods of Ants" and afterwards his published works were mainly devoted to Hymenoptera. His first major entomological work was "A Monograph of the Formicidae of South Africa", published in the Annals of the South African Museum (1914-26). This was followed by "The Sphecidae of the Ethiopian Region" (1922-31) and "The Pompilidae of the Ethiopian Region" (1932-37) in the 
Annals of the Transvaal Museum. A fourth book, The Sphecidae of Madagascar, was printed as a special memoir (No. 1) by the National Museum of Southern Rhodesia (1944). The last major work was entitled "Sphecidae and Pompilidae collected by Mr. K. M. Guichard in West Africa and Ethiopia", published as a bulletin by the British Museum (Natural History) (2, No. 3; 1951). Apart from these monographs many papers, chiefly on Hymenoptera, flowed from his pen; papers on the Formicidae and Methocidae of Africa south of the Zambezi, on the genera of African Apidae (1947), on the Mutillidae of Rhodesia and on the Sphecidae and Pompilidae of the Ethiopian Region; and a chapter on insects in the Victoria Falls Handbook (1952). The Hymenoptera papers continued after his retirement in 1947 and, in fact, right to the end of his days. He was the proud possessor of the honorary fellowship of the Royal Entomological Society of London, and he was elected president of the Rhodesia Scientific Association for the period 1917-19 and vicepresident for several other terms of office.

Of small physical stature Arnold invariably made his presence felt. His alert brain was a formidable weapon in debate or argument, and his ready sense of humour earned him many an admirer even among those who had felt the biting lash of his criticism. He was severely dogmatic and a strong critic in his outlook on scientific workers in his own and other fields, particularly in economic entomology. I first came up against this aspect of his character about twenty years ago. Letters on official matters frequently contained some caustic comment directed at red tape or inefficiency. In his own systematic work he aspired to that point of view of taxonomy described as 'lumping'. 'To those who had only a passing acquaintance his acid comments sometimes caused resentment. But he always gave what he considered an honest opinion and on better acquaintance these traits were accepted as a matter of course, merely one of the characteristies of his active mind.

On any expedition, even into the roughest and wildest places, Arnold must have been almost unique for Africa in turning out immaculately dressed. This outfit would usually be a well-pressed tropical suit complete with waistcoat, tie, watch-chain and trilby. It did not matter what savage tribe or animals might be in the vicinity. In earlier days he was said to have worn spats, rather than leggings, against the attack of snakes, but in later years he evidently decided that long trousers were either adequate protection or at least more comfortable.

Arnold had enjoyed a last brief expedition not long before his death. He had completed his last paper, and I was able to show him the proofs of this-which he signed -on the night he died.

Elitot Pinhey

\section{NEWS and VIEWS}

Director of the National Chemical Laboratory, Teddington : Prof. J. W. Mitchell, F.R.S.

Prof. John Wesley Mitcheld, at present professor of physics in the University of Virginia, is to return to the United Kingdom following his appointment as director of the National Chemical Laboratory, Teddington. He succeeds Dr. J. S. Anderson, who has been appointed to the chair of inorganic chemistry in the University of Oxford (see Nature, 198, 135; 1963). The appointment takos effect from October 1. Prof. Mitchell was born and educated in Now Zealand and is a graduate of the Univorsity of Canterbury. From 1935 until 1938 he was at Trinity College, Oxford, where he obtained his D.Phil While at Oxford he worked with Sir Cyril Hinshelwood on a number of problems in chemical kinetics. During the Second World War he was with the Research Department of the Royal Arsenal, Woolwich, and later with the Ministry of Supply, where he developed high-speed photographic methods of studying the fragmentation of shells and the interaction of armour-piercing projectiles with targets. Prof. Mitchell was appointed lecturer in experimental physics in the University of Bristol in 1945 , and reader in 1948. While at Bristol his main interests wore in the surface properties of thin films of metals and in the nature and formation of the photographic latent image. Since 1959 he has been professor of physics at the University of Virginia, where he has built up a research group for work on the physical and chemical properties of single erystals of metals and other inorganic materials. His personal interests are, at present, principally in the study of the properties of the surfaces of single crystals of metals, in the synthesis of new inorganic matorials and in the production of inorganic erystals of the highest possible chemical purity and physical porfoction and the study of their propertios. Prof. Mitchell was electod a Fellow of the Royal Society in 1956.

\section{Chemistry at University College, London :}

Prof. A. Maccoll

Dr. Altan Maccoll, who was recently appointed by the University of London to a chair of chemistry tenablo at University College as from October 1, 1963, arrived in England from the University of Sydney in 1945 to work on the mechanism of gas-phase reactions in Sir Christopher Ingold's Department at University College. As this work developed, it became apparent that there was a striking analogy betwoen unimolecular gas-phase dehydrohalogenation and the reaction of substitution and elimination of the corresponding compounds occurring in a polar solvent. Further investigations led to the idea that there is a class of unimolecular gas phaso reactions tho mechanism of which is best interpreted as proceeding through a polarized ion pair transition state, and which is essentially heterolytic in character. These ideas received confirmation recently when rearrangements of the Wagner-Meerwein type, characteristic of carbonium ion mechanisms in a polar solvent, were reported for the gas-phase.

The recent installation of a high-resolution mass spectrometer in the Department of Chemistry at University College will greatly extend the scope of Dr. Maccoll's kinetic work, by making possible investigations of the energeties of carbonium-ion formation, and the effects of isotopic substitution on reaction rates. In addition, he hopes to tackle, by mass-spectrometry, problems of the structure of molecules of intermediate molecular weight. While Dr. Maccoll was at the University of Sydney he was awarded a 'blue' for swimming and was elected president of the Science Association, Chemical Society and the Sports Union. He has acted for many years as assistant tutor and adviser to chemistry students at University College, and during 1954-59 he served on the Council of the Chemical Society of London. Dr. Maccoll has long shown a special interest in the developing universities in the overseas territories which participated in the Special Relationship scheme of the University of London. He has from time to time visited them as London examiner in chemistry.

\section{Electrical Engineering at Birmingham :}

Prof. H. A. Prime

Mr. H. A. Prime has been appointed to a new chair of electrical enginoering in the University of Birmingham. The new chair is additional to those already held by Prof. D. G. Tucker (head of the Department) and Prof. J. T, Allanson. Its object is to enable much greater emphasis 